\title{
PELAKSANAAN PROGRAM GERAKAN LITERASI SEKOLAH (GLS) DI SD MUHAMMADIYAH SOKONANDI
}

\author{
Denggan Septiary, Monika Sidabutar \\ Fakultas Ilmu Pendidikan, Universitas Negeri Yogyakarta \\ e-mail: deseptiary@gmail.com; monika.sidabutar@uny.ac.id
}

\begin{abstract}
Abstrak
Penelitian ini bertujuan untuk: (1) mendeskripsikan pelaksanaan program Gerakan Literasi Sekolah (GLS) di SD Muhammadiyah Sokonandi; (2) mendeskripsikan faktor yang mendukung dan menghambat dalam pelaksanaan program Gerakan Literasi Sekolah (GLS) di SD Muhammadiyah Sokonandi. Penelitian ini menggunakan metode deskripstif kualitatif dengan subjek kepala sekolah pendidik serta peserta didik. Metode pengumpulan data menggunakan teknik observasi, teknik wawancara, dan studi dokumentasi. Teknik keabsahan data yang digunakan teknik triangulasi sumber dan teknik triangulasi metode. Hasil penelitian menunjukkan bahwa: (1) dalam pelaksanaan program Gerakan Literasi Sekolah (GLS) mengikuti panduan yang diterbitkan Kemendikbud, namun dilakukan pengembangan secara mandiri sesuai visi dan misi karena sekolah ini merupakan sekolah berbasis agama islam. Proses pelaksanaan program GLS terbagi dalam (a) perencanaa, (b) pelaksanaan, dan (c) evaluasi; (2) faktor pendukung yang ditemukan dalam proses pelaksanaan program GLS yaitu: (a) sarana dan prasarana yang memadai yaitu: 2 unit perpustakaan, pojok baca, laboraturium komputer, lingkungan yang literat (b) alokasi dana yang memadai (c) terjalin kerja sama dengan beberapa lembaga (d) pemanfaatan media. (3) faktor penghambat yang ditemukan dalam proses pelaksanaan program GLS yaitu: (a) perbedaan kemampuan dan inisiatif SDM (b) kurangnya strategi pemusatan perhatian literasi terhadap peserta didik (c) penyelenggaran kegiatan pendukung literasi yang tidak sesuai penjadwalan..
\end{abstract}

Kata Kunci: Program Gerakan Literasi Sekolah, Literasi

\section{IMPLEMENTING THE SCHOOL LITERACY MOVEMENT (SLM) PROGRAM IN SD MUHAMMADIYAH SOKONANDI}

\begin{abstract}
This study aims to: (1) describe the implementation of the School Literacy Movement (GLS) program at SD Muhammadiyah Sokonandi; (2) describe the factors that support and inhibit the implementation of the School Literacy Movement (GLS) program in SD Muhammadiyah Sokonandi. This study uses a qualitative descriptive method with the subject of school principals, educators and students. Data collection methods using observation techniques, interview techniques, and study documentation. Validity technique for data used source triangulation technique and method triangulation technique. The results showed that: (1) in the implementation of the School Literacy Movement (GLS) program, following the guidelines issued by the Ministry of Education and Culture, the development was carried out independently according to the vision and mission because this school is an Islamic-based school. The process of implementing the GLS program is divided into (a) planning, (b) implementation, and (c) evaluation; (2) supporting factors found in the process of implementing the GLS program, namely: (a) adequate facilities and infrastructure, i.e.: 2 library units, reading corners, computer laboratories, a literate environment (b) adequate funding allocation (c) cooperation is established with several institutions (d) media use. (3) the inhibiting factors found in the process of implementing the GLS program, i.e.: (a) differences in ability and HR initiatives $(b)$ lack of a strategy of focusing literacy on students (c) organizing literacy support activities that do not fit the scheduling.
\end{abstract}

Keywords: School Literacy Movement Program, Literacy

\section{PENDAHULUAN}

Keterampilan literasi yang baik akan berpengaruh terhadap perkembangan kemampuan berpikir setiap individu. Kemampuan literasi akan membantu setiap individu untuk memahami informasi dengan bijak dan teliti dalam kehidupan sehari-hari. Hal ini sejalan dengan pernyataan UNESCO yang menjelaskan bahwa kemampuan literasi merupakan hak setiap individu dan merupakan dasar untuk belajar sepanjang hayat. Selain itu kegiatan literasi berperan penting dalam dunia pendidikan untuk memiliki wawasan pengetahuan yang luas. Namun pada kenyataannya masyarakat di Indonesia masih belum memiliki kesadaran akan pentingnya kegiatan literasi.

Pemerintah berupaya untuk mendorong peningkatan minat baca dan kegiatan literasi dengan digalakkannya program Gerakan Literasi Sekolah (GLS). Cakupan dari program 
ini adalah warga sekolah dari sekolah dasar hingga sekolah menengah. Program ini mengarahkan warga sekolah untuk mampu mengakses, memilih, dan memanfaatkan informasi secara tepat guna dalam kehidupan sehari-hari. Sehingga peserta didik mempunyai pemahaman untuk menyaring setiap informasi yang diterima dan menggunakannya dengan tepat. Dengan demikian kasus-kasus hoaks yang marak beredar dapat diminimalisir.

Program Gerakan Literasi Sekolah berlandaskan dengan Peraturan Menteri Pendidikan dan Kebudayaan Nomor 23 Tahun 2015 tentang Penumbuhan Budi Pekerti. Salah satu tujuan dari Permendikbud tersebut adalah menjadikan pendidikan sebagai gerakan yang melibatkan seluruh komponen yang berkaitan dengan penyampaian informasi kepada peserta didik sebagai bentuk gerakan literasi. Dengan keterlibatan dan pembiasaan seluruh komponen lembaga dalam pelaksanaan GLS ini, akan membentuk individu sebagai pebelajar sepanjang hayat.

Program GLS mulai diikuti dan dilaksanakan diseluruh satuan pendidikan sesuai dengan arahan dari Kemendikbud sejak disahkannya program ini mulai Maret 2016 lalu. Contohnya, di Kota Yogyakarta terdapat 11 SMA Negeri yang seluruhnya menerapkan GLS. Selain itu SMP Muhammadiyah 3 Yogyakarta dan SD Muhammadiyah Wirobrajan 3.

Selain beberapa sekolah yang telah disebutkan sebelumnya, SD Muhammadiyah Sokonandi adalah salah satu sekolah di Daerah Istimewa Yogyakarta yang juga melaksanakan program GLS dari Kemendikbud ini, sesuai dengan arahan dan tahapan buku panduan GLS.

Berdasarkan pengamatan dan wawancara yang dilakukan pada kurun waktu Juni hingga Agustus 2019, dengan kepala sekolah dan pendidik diperoleh informasi meliputi: diluar kegiatan literasi 15 menit SD Muhammadiyah Sokonandi menyusun kegiatan untuk mendukung pelaksanaan GLS, seperti dengan pengadaan pojok baca disetiap kelas, kegiatan kerohanian rutin sebelum jam pembelajaran, penempelan pamflet, poster, dan lukisan (karya peserta didik dari hasil literasi) disetiap sudut sekolah dan didalam kelas bahkan penempelan stiker kalimat positif disetiap tangga sekolah. Sekolah memfasilitasi pojok baca disetiap kelas untuk menunjang peserta didik agar terbiasa dan gemar berliterasi, meskipun hasil observasi menunjukkan bahwa buku yang berada di pojok baca kelas masih terbatas, serta perpustakaan sekolah yang terbagi dalam 2 unit.

Perpustakaan yang terbagi dalam 2 unit ini memudahkan dalam pengelompokan dan penyediaan buku untuk peserta didik, karena kebutuhan setiap jenjang berbeda. Sebagai contohnya perpustakaan unit 1 yang diperuntukan untuk peserta didik kelas rendah menyediakan buku dan fasilitas untuk menekankan dan mendukung kemampuan literasi dasar. Seperti buku kitabah, buku cerita bergambar, buku mengenal huruf, buku mengenal bahasa, dan lain sebagainya. Sedangkan perpustakaan unit 2 yang diperuntukkan untuk peserta didik kelas tinggi menyediakan buku yang sesuai dengan kebutuhan mereka untuk mengembangkan literasi pada tingkat lanjut. Seperti buku cerita, buku ensiklopedia, referensi materi pembelajaran, majalah, buku kumpulan puisi, buku sejarah, dan lain sebagainya.

Pada kesempatan yang sama peneliti melakukan pengamatan berkaitan dengan ketersediaan buku yang ada di perpustakan. Di perpustakaan terdapat buku hasil kerja sama sekolah dengan Universitas Gajah Mada dan Universitas Ahmad Dahlan dalam bentuk cerita bergambar. Selain kerjasama tersebut SD Muhammadiyah Sokonandi berkerja sama dengan penerbit Platinum dan tim Ganesha Operation untuk mendukung referensi buku pembelajaran. Namun berdasarkan observasi yang telah dilakukan buku yang berada diperpustakaan masih terbatas dan kurang variatif karena didominasi buku dinas.

Selanjutnya pihak sekolah menyelenggarakan kegiatan mendongeng dengan menghadirkan narasumber, ekstrakulikuler yang relevan, dan pembiasaan literasi yang terkemas dalam pembelajaran. Kegiatan tersebut dilaksanakan sebagai upaya menanamkan budaya literasi pada peserta didik agar gemar berliterasi dan memfasilitasi peserta didik untuk mengembangkan potensinya dalam bidang literasi. Namun dalam pelaksanaan kegiatan pendukung literasi tersebut masih belum optimal dan sering kali terhambat karena berbagai kegiatan wajib sekolah.

Selain yang telah diuraikan diatas SD Muhammadiyah Sokonandi melahirkan berbagai prestasi dalam bidang literasi seperti penghargaan mendongeng, tausiah cilik, menulis puisi, seni suara, dan penciptaan cerita bergambar. Hal tersebut didukung dengan observasi yang dilakukan pada tanggal 21 Januari 2020 menunjukkan bahwa peserta didik 
sedang berlatih untuk membawakan tausiah dan mendongeng. Tidak hanya prestasi diluar kelas saja, SD Muhammadiyah Sokonandi memulai pemberian apresiasi terhadap peserta didik melalui papan prestasi yang berada disetiap kelas sebagai pendukung penciptaan lingkungan sosial afektif dan akademik sebagai model komunikasi dan interaksi yang literatur sesuai dengan buku panduan GLS di SD.

Beriringan dengan penanaman literasi dasar tersebut sekolah menyelenggarakan berbagai kegiatan untuk menambah kemampuan literasi yang lain seperti kemampuan literasi perpustakaan dan literasi media yang dikemas dalam kegiatan pembelajaran. Salah satu bentuk dari literasi media tersebut adalah pemanfaatan video sebagai media pembelajaran, pemanfaatan internet, buku dan koran sebagai sumber belajar. Disamping itu SD Muhammadiyah Sokonandi memanfaatkan laboraturium komputer untuk proses pembelajaran.

Oleh karena itu, peneliti tertarik untuk mengkaji lebih dalam mengenai pelaksanaan program GLS di SD Muhammadiyah Sokonandi untuk mendeskripsikan pelaksanaan program GLS yang dilaksanan di SD Muhammadiyah Sokonandi dan mengetahui faktor pendukung serta penghambat pelaksanaan program GLS di SD Muhammadiyah Sokonandi.

\section{METODE}

Penelitian ini menggunakan pendekatan kualitatif untuk mengetahui pelaksanaan program Gerakan Literasi Sekolah di SD Muhammadiyah Sokonandi. Jenis penelitian yang digunakan dalam penelitian ini adalah kualitatif deskriptif.

\section{Setting Penelitian}

Setting penelitian ini terbagi dalam dua kategori, yaitu tempat dan waktu. Tempat penelitian ini adalah SD Muhammadiyah Sokonandi yang beralamatkan di Jl. Kapas No 5A, Semaki, Umbulharjo, Kota Yogyakarta, Daerah Istimewa Yogyakarta. Penelitian dilakukan mulai Juni 2019 dan berakhir pada awal Februari 2020 dikarenakan data yang sudah jenuh.

\section{Subjek dan Objek Penelitian}

Subjek penelitian adalah warga sekolah yang meliputi 2 kepala sekolah, 2 kepala bidang, 2 pendidik, dan peserta didik. Objek penelitian ini adalah situasi sosial, interaksi sosial yang menggambarkan pelaksanaan program Gerakan Literasi Sekolah di SD Muhammadiyah Sokonandi.

\section{Teknik Pengumpulan Data dan Instrumen Pengumpulan Data}

Teknik pengumpulan data dan instrumen pengumpulan data yang digunakan dalam penelitian ini adalah:

1. Observasi

Observadi yang digunakan peneliti dalam penelitian adalah observasi tidak terstruktur. Observasi yang dilakukan berkaitan dngan pengamatan objek di lingkungan sekolah yang berkaitan dengan GLS. Instrumen pengumpulan data yang digunakan adalah pedoman observasi.

2. Wawancara

Peneliti menggunakan wawancara tak terstruktur untuk menggali keterangan dari subjek penelitian terkait dengan pelaksanaan Gerakan Literasi Sekolah di SD Muhammadiyah Sokonandi. Instrumen pengumpulan data yang digunakan adalah pedoman wawancara.

3. Studi Dokumentasi

Dokumentasi ini dilakukan untuk memperkuat dan mendukung data terkait pelaksanaan program Gerakan Literasi Sekolah di SD Muhammadiyah Sokonandi. Dokumentasi ini dapat berupa file, foto, video, dan yang yang ada di SD Muhammadiyah Sokonandi. Dokumentasi tersebut digunakan sebagai bukti untuk memperkuat pengamatan peneliti dilapangan.

\section{HASIL DAN PEMBAHASAN}

\section{Hasil}

Hasil penelitian ini menyajikan data tentang Pelaksanaan Program Gerakan Literasi Sekolah (GLS) di SD Muhammadiyah Sokonandi. Tahap penelitian dalam pelaksanaan GLS ini terbagi atas perencanaan, pelaksanaan, dan evaluasi.

1. Perencanaan

Dalam perencanaa pelaksanaan program gerakan literasi sekolah di SD Muhammadiyah Sokonandi mengacu pada Permendikbud No 23 Tahun 2015 yang kemudian dikembangkan secara mandiri oleh sekolah, karena sekolah ini menerapkan kurikulum irisan yaitu kurikulum nasional, karakter building/muhammadiyah, dan program plus. Oleh karena itu pihak sekolah melakukan berbagai terobosan untuk mendukung program GLS ini. 
Perencanaan dan persiapan dilakukan saat penyusunan pengembangan kurikulum dibawah kepala bidang kurikulum. Perencanaan tersebut diturukan dalam penjadwalan kegiatan pembelajaran yang akan dilaksanakan setiap hari. Seperti penyelenggaraan program plus pada awal pembelajaran, perencanaan pembelajaran, dan penambahan jam pembelajaran. Selain itu dilakukan penyusunan RPP sebagai pedoman kegiatan pembelajaran. Rancangan kegiatan yang telah disusun kemudian akan didokumentasikan dan diberikan penilaian oleh supervisi sekolah. Kedudukan supervisi ini dilakukan oleh kepala sekolah atau kepala dinas terkait. Tujuannya adalah untuk meninjau kembali rencana kegiatan dan disesuaikan dengan kebutuhan sekolah. Selain perencanaan di atas SD Muhammadiyah Sokonandi melakukan perencanaan sumber daya manusia, sumber daya fasilitas, dan sumber daya pendanaan serta hubungan antar organisasi.

a. Sumber Daya Manusia

Sumber daya manusia adalah orang yang memberikan dukungan untuk keterlaksanaan program gerakan literasi sekolah dan memiliki komitmen untuk terlibat didalamnya. Dalam perencanaan sumber daya manusia yang dilakukan SD Muhammadiyah Sokonandi adalah dengan mengikuti pelatihan/diklat terkait dengan pelaksanaan gerakan literasi sekolah.

b. Sumber Daya Fasilitas

Berdasarkan observasi yang telah dilakukan SD Muhammadiyah Sokonandi memiliki fasilitas perpustakaan, laboratorium komputer, pojok baca, dan dinding karya. Selain itu lingkungan yang literat dikembangkan untuk mendukung keterlaksanaan program GLS ini. Seperti pemanfaatan tangga yang ditempeli dengan stiker kalimat positif, pemasangan dinding sekolah dengan poster pembelajaran, mading, dan penempelan hasil karya peserta didik pada dinding karya. Selain itu studi dokumentasi menunjukkan bahwa peserta didik menghasilkan karya dalam bentuk gambar, kliping, dan cerita bergambar.

c. Sumber Daya Pendanaan

Sumber daya pendaan dalam keterlaksanaan program gerakan literasi sekolah di SD Muhammadiyah Sokonandi berasal dari RAPBS, DKT, dan dana mandiri yang dibayarkan oleh orang tua peserta didik. Seperti penambahan jam pembelajaran diluar jam belajar sekolah dan ekstrakurikuler.

d. Hubungan Antar Organisasi

Dalam pelaksanaan gerakan literasi sekolah SD Muhammadiyah Sokonandi menjalin hubungan dengan organisasi terkait sebagai penunjang pelaksanaan gerakan literasi sekolah. Hubungan yang terjalan adalah hubungan dengan Dinas Pendidikan Kota Yogyakarta, komite sekolah, paguyuban wali murid, dan Pimpimnan Daerah Muhammadiyah. Kerjasama yang terjalin antara SD Muhammadiyah Sokonandi dan relasinya tersebut terbagi kedalam dua bidang yaitu nasional dan keagamaan. Pada bidang nasional pengembangan gerakan literasi sekolah berpatokan dengan panduan resmi dari Permendikbud. Sedangkan pada bidang keagamaan pengembangan dilakukan dengan PDM sesuai dengan kurikulum ke-Muhammadiyahan. Studi dokumentasi berupa majalah mentari juga ditemukan sebagai hasil kerja sama pihak sekolah dengan PDM.

2. Pelaksanaan

a. Pembiasaan

Pada tahap pembiasaan pendidik mengarahkan peserta didik untuk melakukan kegiatan literasi setiap hari. Kegiatan tersebut dapat dilakukan pada awal pembelajaran, tengah pembelajaran, atau akhir pembelajaran. Pendidik memberikan kebebasan kepada peserta didik untuk memilih buku bacaan yang mereka minati. Akan tetapi karena SD Muhammadiyah Sokonandi adalah sekolah berbasis agama, pembelajaran agama yaitu tahsin, tahfidz, dan hafalan Al-Qur'an lebih ditekankan. Pendidik lebih mengutamakan pembelajaran berbasis agama. Dengan adanya kegiatan tersebut peserta didik menjadi terbiasa dengan kegiatan literasi. Mereka sangat antusias dalam memilih buku bacaan dan membacanya. Program gerakan literasi sekolah efektif untuk mengarahkan peserta didik pada pembiasaan membaca setiap harinya.

b. Pengembangan

Pelaksanaan gerakan literasi sekolah di SD Muhammadiyah Sokonandi dikembangkan dan dimodifikasi secara 
mandiri oleh pendidik disesuaikan dengan kondisi kelas. Pendidik diberikan kebebasan untuk melakukan pengembangan dalam pelaksanaan gerakan literasi sekolah. Selain dengan bercerita didepan kelas pendidik memberikan pendampingan kepada peserta didik untuk membaca nyaring dan mendengarkan sekaligus mencatat yang disampaikan pendidik dengan nyaring.

Membaca buku secara mandiri dilakukan peserta didik setiap hari sebagai bagian dari tahap pembiasaan ke tahap selanjutnya yaitu pengembangan. Berdasarkan observasi pada Selasa, 21 Januari 2020 peserta didik secara mandiri memilih buku yang akan dibaca dari pojok baca kelas. Kemudian secara bersamaan mereka membaca buku tersebut sambil bercerita bersama. Bahkan peserta didik ada yang menyiapkan sendiri teks bacaannya.

Observasi yang dilakukan pada Selasa, 21 Januari 2019 menunjukkan bahwa pengembangan literasi peserta didik sampai pada menghafal dialog untuk drama, pembukaan tausiah anak, dan bercerita. Kegiatan menghafal ini dilakukan saat ada waktu luang seperti saat istirahat. Peserta didik menyiapkan teks bacaannya secara mandiri. Berawal dari kegiatan seperti ini peserta didik dapat memperoleh prestasi penghargaan dalam bidang tausiah dan mendongeng. Selain itu dalam kegiatan milad sekolah juga diadakan kegiatan pildacil sebagai penyaringan bakat yang dimiliki peserta didik.

Dari uraian diatas dapat disimpulkan bahwa pada tahap pengembangan program gerakan literasi sekolah ini peserta didik melakukan berbagai hal, seperti penyampaian cerita dan berbagai cerita di depan kelas, membaca nyaring, menulis, menghafal teks dialog, membaca mandiri, dan membaca bersama serta diskusi. Peserta didik antusias dalam memanfaatkan pojok baca dan perpustakaan sekolah.

c. Pembelajaran

Tahap pembelajaran ini merupakan tingkatan ke tiga dari tahap pelaksanaan gerakan literai sekolah. Tahap pembelajaran ini merupakan kelanjutan dari tahap mengembangan. Pada tahap ini peserta didik sampai pada memanfaatkan kemampuan literasi dalam pembelajaran setiap hari untuk menyelesaikan dan menguasai materi yang disampaikan pendidik melalui kegiatan pembelajaran.

Pada tahap pembelajaran tingkat SD kelas rendah menekankan pada kecakapan peserta didik untuk mengenal huruf, menulis, membaca, memahami kalimat dan konteksnya, menginterpretasi dan merespon bacaan. Peserta didik belajar mengeja huruf dalam pembelajaran. Oleh karena itu, untuk mendukung pembelajaran tersebut pendidik memberikan buku menulis bergaris dan berpetak dengan tujuan agar peserta didik lebih mudah dalam berlatih mengejar huruf yang mereka tuliskan.

Pembelajaran dapat dikembangan dengan berbagai metode dan strategi, seperti penggunaan media untuk membantu penyampaian materi pembelajaran. Media tersebut dapat digunakan sebagai saluran untuk memberikan pengalaman literasi yang lebih mendalam dan berkesan. Misalnya penggunaan media video yang dilakukan pendidik untuk menyampaikan materi. Pada saat penyampaian materi kisah Nabi Muhammad pendidik menggunakan media video dan diikuti interaksi dari peserta didik yaitu bernyanyi. Hal tersebut ditunjukkan saat observasi pada Selasa, 21 Januari 2020.

Strategi pembelajaran yang digunakan pendidik untuk meningkatkan kemampuan literasi peserta didik beragam. Hasil observasi pada Selasa, 21 Januari 2020 menunjukkan bahwa pendidik menggunakan pemecahan masalah dan eksplorasi untuk menyampaikan materi cuaca. Pendidik membaca nyaring permasalahan dan soal kemudian peserta didik mendengarkan lalu menulis. Pada penyelesaian masalah tersebut peserta didik diberikan kebebasan untuk mencari sumber yang dapat digunakan untuk memecahkan masalah. Berdasarkan hasil observasi peserta didik mencari pada buku dan melihat keadaan alam sekitar yang ditemui.

Dari uraian diatas dapat disimpulkan bahwa pelaksanaan program gerakan literasi 
sekolah sampai pada tahap pembelajaran dimana peserta didik menggunakan literasi dalam setiap pembalajaran. Hal tersebut dibuktikan dengan penggunaan strategi pembelajaran yang mendukung oleh pendidik, pendampingan untuk peserta didik, hasil karya peserta didik, dan eksplorasi yang dilakukan oleh peserta didik. Selain itu penciptaan karya peserta didik seperti kliping dan cerita bergambar juga menjadi bukti bahwa kegiatan literasi sampai pada penciptaan karya yang berkaitan dengan materi pembelajaran. sebagai contohnya pembuatan kliping yang merujuk pada tema cuaca yang berada dikelas 3 serta pembuatan cerita bergambar yang merujuk pada mata pelajaran matematika. Karya ini selanjutnya digunakan pendidik sebagai penilaian tambahan dan dirujuk sebagai referensi oleh kelas yang lain.

3. Evaluasi

Evaluasi dilakukan untuk memberikan penilaian secara menyeluruh terhadap pelaksanaan sebuah program yang terstruktur. Evaluasi tersebut dapat dilakukan dalam bentuk evaluasi formatif atau sumatif. Evaluasi formatif adalah evaluasi yang dilakukan pada tengah pelaksanaan program sebagai tolak ukur dan umpan balik sedangkan evaluasi sumatif adalah evaluasi yang dilakukan pada akhir program untuk mengetahui sejauh mana program tersebut dapat dilaksanakan.

Pada pelaksanaan gerakan literasi sekolah di SD Muhammadiyah Sokonandi ini lebih banyak menggunakan evaluasi formatif. Hal tersebut ditunjukkan berdasarkan observasi yang telah dilakukan pada 27 Januari 2020. Evaluasi tersebut dilakukan oleh pendidik saat proses pembelajaran sedang berlangsung, tujuannya adalah untuk memberikan pantauan pada setiap perkembangan peserta didik dan memberikan umpan balik untuk peserta didik secara berkala.

Evaluasi sumatif dilakukan pada akhir semester yang bertujuan untuk mengambil keputasan pada langkah selanjutnya. Apakah program tersebut dapat dilanjutkan atau memerlukan perbaikan. Selain itu evaluasi dilakukan setiap hari senin minggu ke-2 setiap bulannya. Evaluasi ini diikuti seluruh komponen dan berbentuk diskusi serta story telling sesuai pengalaman masing-masing pendidik.

4. Faktor Penghambat dan Pendukung dalam Pelaksanaan GLS

Pelaksanaan suatu program tentu akan terdapat faktor-faktor yang menjadi pendukung ataupun penghambat. Berikut adalah faktor pendukung dan penghambat dalam pelaksanaan program Geraka Literasi Sekolah di SD Muhammadiyah Sokonandi:

a. Faktor Pendukung

Berdasarkan hasil observasi dan wawancara yang dilaksanakan bahwa terdapat beberapa faktor pendukung yaitu:

1. Adanya sarana dan prasarana yang memadai, seperti perpustakaan, pojok baca, laoraturium komputer, proyektor disetiap kelas, lingkungan yang literat (dinding karya, papan prestasi, poster, kalimat positif di area sekolah, dan pemajangan penghargaan/piala prestasi peserta didik) yang dapat digunakan sebagai penunjang peningkatan program GLS.

2. Alokasi dana untuk kegiatan literasi yang memadai.

3. Terjalinnya kerja sama dengan beberapa organisasi seperti Dinas Pendidikan, Perpustakaan Keliling daerah, Ikhwam wali murid, dan komite sekolah untuk meningkatkan kegiatan literasi.

4. Adanya sodaqoh buku dari komite sekolah dan paguyuban wali murid.

5. Pemanfaatan media sebagai sumber literasi yang terus dikembangkan.

6. Adanya grup paguyuban wali murid sebagai jembatan penghubung antara sekolah dan keluarga.

b. Faktor Penghambat

Berdasarkan hasil observasi dan wawancara yang dilaksanakan bahwa terdapat beberapa faktor penghambat yaitu:

1. Perbedaan kemampuan dan inisiatif setiap SDM dalam mengembang program pendukung program GLS.

2. Kondisi peserta didik yang cepat bosan dan perhatian yang mudah berpindah membuat pendidik harus memberikan dorongan motivasi belajar.

3. Penyelenggaran program pendukung kegiatan literasi yang masih perlu ditingkatkan. 


\section{Pembahasan}

\section{Perencanaan}

Dalam perencanaa pelaksanaan program gerakan literasi sekolah di SD Muhammadiyah Sokonandi mengacu pada Permendikbud No 23 Tahun 2015 yang kemudian dikembangkan secara mandiri oleh sekolah, karena sekolah ini menerapkan kurikulum irisan yaitu kurikulum nasional, karakter building/muhammadiyah, dan program plus. Oleh karena itu pihak sekolah melakukan berbagai terobosan untuk mendukung program GLS ini. Perencanaan dan persiapan dilakukan saat penyusunan pengembangan kurikulum dibawah kepala bidang kurikulum. Perencanaan tersebut diturunkan dalam penjadwalan kegiatan pembelajaran yang akan dilaksanakan setiap hari yang terbagi dalam kegiatan semester dan kegiatan pembelajaran setiap hari. Kemudian pendidik akan membuat rancangan pembelajaran (RPP) yang digunakan sebagai pedoman pembelajaran. Dalam RPP tersebut dituliskan kompetensi dasar yang harus dicapai, langkah-langkah kegiatan pembelajaran yang meliputi strategi pembelajaran, bahan ajar yang digunakan, media pendukung kegiatan belajar, dan penilaian pembelajaran untuk peserta didik. Dengan adanya RPP ini pendidik lebih mudah untuk mengendalikan dan mengelola kelasnya.

a. Sumber Daya Manusia

Dalam pelaksanaan GLS di SD Muhammadiyah Sokonandi mempersiapkan pustakawan yang diberikan tugas untuk mengembangan kemampuan literasi dan minat baca warga sekolah melalui kegiatan yang disusun. Pustakwan tersebut berkedudukan dibawah kepala sekolah dan bekerja pada ranah pengembangan kegiatan literasi. Sekolah ini mempunyai 2 orang pustakawan pada 2 unit sekolah yang bekerjasama untuk meningkatkan kualitas perpustakaan. Kegiatan yang dilakukan oleh pustakawan ini adalah melayani peminjaman buku yang dilakukan peserta didik, memberikan pendampingan kepada peserta didik saat peserta didik memanfaatkan perpustakaan, dan mengarahkan pemilihan buku peserta didik sesuai dengan kemampuan dan tingkatannya.

b. Sumber Daya Failitas

Sumber daya fasilitas merupakan sarasan fisik yang dibutuhkan untuk menunjang pelaksanaan program gerakan literasi sekolah ini. Sumber daya fasilitas yang dimiliki SD Muhammadiyah Sokonandi sebagai penunjang adalah sarana prasarana. Sekolah memiliki berbagai fasilitas seperti laboraturium komputer, perpustakaan, pojok baca, dan dinding karya yang didukung dengan lingkungan literat seperti pemanfaatan tangga sekolah yang ditempel dengan stiker kalimat positif dan penempelan poster pembelajaran pada dinding-dinding sekolah. Lingkungan literat tersebut terus dikembangkan oleh sekolah agar peserta didik terbiasa dengan literasi dimana saja mereka berada. Bahkan diarea kantin dan halaman sekolah sebagai area bermain peserta didik didukung dengan pemasangan poster dan kalimat positif. Dengan demikian peserta didik akan terbiasa dengan berbagai jenis bacaan.

c. Sumber Daya Pendanaan

Sumber daya pendaan dalam keterlaksanaan program gerakan literasi sekolah di SD Muhammadiyah Sokonandi berasal dari RAPBS, DKT, dan dana mandiri yang dibayarkan oleh orang tua peserta didik. Dana tersebut kemudian dialokasikan untuk keterlaksanaan program pendukung pelaksanaan GLS, seperti pembelian buku dan perbaikan fasilitas sekolah, serta program yang terintegrasi dalam kegiatan pembelajaran.

d. Hubungan Antar Organisasi

Hubungan dengan Dinas Pendidikan bagian kearsipan menghasilkan kegiatan rutin tahunan yang diikuti SD Muhammadiyah Sokonandi yaitu kegiatan merangsang anak untuk meningkatkan kemampuan literasi melalui lomba bercerita dan menulis serta majalah yang diterbitkan oleh dinas pendidikan yang didalamnya termuat kolom untuk menampilkan karya peserta didik. Kerja sama dengan perpustakaan daerah berupa kegiatan perpustakaan keliling 2 kali dalam 1 minggu untuk menambah buku bacaan peserta didik. Jadi saat perpustakaan keliling tiba disekolah peserta didik diberikan kebebasan untuk memilih dan meminjam buku bacaan sesuai dengan minat masing-masing. Selanjutnya kerja sama dengan komite sekolah berubah kegiatan sodakoh buku yang dilakukan oleh komite sekolah untuk menambah koleksi 
buku bacaan yang berada diperpustakaan sekolah. Paguyuban wali murid di SD Muhammadiyah Sokonandi kooperatif dalam menyediakan buku di pojok baca kelas yang digunakan peserta didik sewaktu-waktu. Sedangkan kerja sama dengan PDM berupa perencanaan kegiatan keagamaan dan penerbitan buku mentari dari Muhammadiyah.

\section{Pelaksanaan}

a. Pembiasaan

Pada tahap pelaksanaan pembiasaan GLS ini bertujuan untuk menumbuhkan minat peserta didik terhadap bacaan dan terhadap kegiatan membaca. Berdasarkan Buku Panduan Gerakan Literasi Sekolah di SD pada tahap pembiasaan ini peserta didik diarahkan untuk membaca buku selama 15 menit setiap harinya. Pembiasaan membaca tersebut dapat dilakukan pada awal pembelajaran, tengah pembelajaran, dan akhir pembelajaran. Tahap pembiasaan yang berlangsung di SD Muhammadiyah Sokonandi dimulai sejak peserta didik duduk dibangku kelas 1. 15 menit sebelum jam pembelajaram dimulai pendidik akan masuk keruang kelas dan memandu serta memfasilitasi peserta didik untuk membaca.

Pembiasaan pada peserta didik di SD Muhammadiyah Sokonandi meliputi pembiasaan membaca tahsin, tahfidz, tadarus, doa, hafalan, dan membaca pengetahuan umum. Pembiasaan ini dilakukan dengan bertahap. Pada kelas rendah kegiatan tersebut masuk kedalam proses pembelajaran yaitu dalam bentuk baca tulis Al-Qur'an dan huruf latin dan terintegrasi dalam program plus. Penyelenggaraan program plus ini terfokus pada pengembangan literasi dasar. Sedangkan untuk kelas tinggi pembiasaan akan berada pada tingkatan yang berbeda yaitu dengan menulis huruf arab panjang, hafalan yang ditingkatkan, dan pengetahuan umum yang lebih luas. Penjenjangan ini dilakukan agar peserta didik terus berkembang naik pada tahap yang lebih tinggi dan mampu menciptakan karya.

b. Pengembangan

Kegiatan literasi pada tahap pengembangan bertujuan untuk mempertahankan minat terhadap bacaan dan terhadap kegiatan membaca, serta meningkatkan kelancaran dan pemahaman membaca peserta didik. Untuk mempertahankan minat baca peserta didik sebagai hasil dari pembiasaan dilakukan pengembangan dalam pelaksanaan program GLS ini. Pengembangan ini dilakukan secara mandiri oleh pendidik yang termasuk kedalam kegiatan pembelajaran. Pengembangan yang dilakukan disesuaikan dan dibatasi sesuai dengan tujuan pembelajaran yang akan dicapai.

Pengembangan pembelajaran dapat dilakukan dengan penerapan metode pembelajaran yang vareatif untuk melibatkan interaksi peserta didik dengan buku bacaan. Pada observasi yang dilakukan pada Selasa, 21 Januari 2020, pendidik di SD Muhammadiyah Sokonandi menggunakan metode pemecahan masalah sebagai pengembangan literasi. Dalam pembelajaran pendidik membaca nyaring dan peserta didik menulis pada buku masing-masing. Dengan demikian pemahaman peserta didik terhadap permasalahan yang disampaikan pendidik juga dapat ditingkatkan. Tujuannya adalah agar peserta didik memecahkan permasalahan dengan membaca dengan demikian minat membaca peserta didik dapat terjaga dan dapat ditingkatkan. Dalam perancangan pembelajaran berbentuk RPP yang akan digunakan sebagai panduan dalam pembelajaran. Sedangkan teknologi pembelajaran dapat dikembangkan dengan pemanfaatan media untuk memfasilitasi proses belajar peserta didik. Tujuan penggunaan media ini adalah sebagai pemusatan perhatian peserta didik sehingga kemampuan literasi peserta didik dan pemahamannya dapat ditingkatkan. Berkitan dengan hal tersebut SD Muhammadiyah Sokonandi memanfaat media sebagai sumber belajar. Pendidik menggunakan video, poster, cerita bergambar dalam pengembangan literasi sebagai pendukung buku yang berada di pojok baca kelas serta perpustakaan.

Perpustakaan dan pojok baca di dalam kelas dapat menjadi pusat sumber belajar yang efektif untuk digunakan peserta didik belajar. Sama halnya dengan SD 
Muhammadiyah Sokonandi yang menggunakan perpustakaan dan pojok baca di dalam kelas sebagai pendukung utama dalam pelaksanaan pengembangan program GLS. Dalam pemanfaatannya peserta didik antusias dan memiliki minat yang cukup tinggi dalam membaca buku. Hal tersebut dapat dibuktikan dengan hasil observasi pada Selasa, 21 Januari 2020 yang menunjukkan bahwa peserta didik memanfaatkan perpustakaan serta pojok baca sebagai sumber belajarnya.

c. Pembelajaran

Kegiatan literasi pada tahap pembelajaran bertujuan untuk mempertahankan minat peserta didik terhadap bacaan dan terhadap kegiatan membaca, serta meningkatkan kecakapan literasi peserta didik melalui buku-buku pengayaan dan buku teks pelajaran. Kegiatan literasi pada tahap pembelajaran meningkatkan kemampuan berbahasa reseptif (membaca dan menyimak) dan aktif (berbicara dan menulis) yang dijelaskan secara rinci dalam konteks dua kegiatan utama di tahap ini, yaitu membaca dan menulis. Kemampuan membaca dan menulis dijenjangkan agar peningkatan kecakapan di empat area berbahasa tersebut (membaca, menyimak, berbicara, dan menulis) dapat dilakukan secara terukur dan berkelanjutan.

Pada tahapan ini SD Muhammadiyah Sokonandi mengintegrasikan literasi dalam kegiatan pembelajaran. berdasarkan hasil observasi yang dilakukan pada Kamis, 16 Januari 2020 pada kelas rendah peserta didik difokuskan pada kemampuan membaca dan menulis. Untuk jenjang kelas 1 peserta didik ditargetkan dapat membaca dan menulis dengan lancar baik tulisan huruf arab pendek maupun tulisan latin sesuai dengan tingkat kemampuan peserta didik yang berada dikelas rendah. Sebagai pendukung peningkatan kemampuan peserta didik tersebut sekolah menerbitkan buku khusus menulis yaitu buku kitabah, buku tahsin, buku bergaris dan buku berpetak. Tujuannya adalah agar peserta didik lebih mudah dalam mengeja dan menulis huruf. Selain itu pendidik akan memberikan pendampingan khusus bagi peserta didik yang belum mengusai materi yang disampaikan pendidik. Pendampingan ini dilakukan saat jam pembelajaran usai sebagai bentuk fasilitas dan dukungan yang diberikan kepada peserta didik. Dengan adanya pendampingan seperti ini peserta didik dapat mengejar ketertinggalannya dan meningkatkan kemampuan baca tulis yang dicapainya.

Tahap pembelajaran yang berada di kelas tinggi membaca dan menulis dikembangkan dalam tingkatan yang lebih tinggi yaitu dapat menulis arab panjang dan menulis cerita, dongeng, puisi, cerita bergambar, kliping dan membaca dengan lancar sebagai hasil dari pembelajaran bidang literasi. Dalam pembuatan karya dan porto folio peserta didik ini, pendidik memberikan fasilitas pendampingan dan pengarahan sebagai bagian dari tugas pendidik sebagai fasilitator.

SD Muhammadiyah merancang berbagai program yang terintegrasi dalam pembelajaran untuk membentuk lingkungan akademik yang literat. Terdapat program plus (tahsin, tahfidz, hafalan, doa, dan bahasa inggris) yang dilaksanakan setiap hari sebelum pembelajaran untuk meningkatkan literasi peserta didik, gerakan membaca sebelum jam pembelajaran, dan mengisi waktu luang peserta didik dengan kegiatan literasi. Alokasi waktu yang digunakan untuk kegiatan literasi ini fleksibel dan disesuaikan dengan kondisi kelas.

\section{Evaluasi}

Pada pelaksanaan gerakan literasi sekolah di SD Muhammadiyah Sokonandi ini lebih banyak menggunakan evaluasi formatif. Hal tersebut ditunjukkan berdasarkan observasi yang telah dilakukan pada 27 Januari 2020. Evaluasi tersebut dilakukan oleh pendidik saat proses pembelajaran sedang berlangsung, tujuannya adalah untuk memberikan pantauan pada setiap perkembangan peserta didik dan memberikan umpan balik untuk peserta didik secara berkala. Pada proses evaluasi ini pendidik memberikan penilaian baik akademik maupun non-akademik atas keterlibatannya melaksanakan program GLS. Nilai akademik diberikan dengan penilaian yang masuk pada pembelajaran bahasa indonesia dan hasil karya peserta didik. sedangkan penilaian nonakademik dihasilkan dari perubahan dan perkembangan peserta didik dilihat segi sikap dalam pelaksanaan program GLS ini.

Sedangkan evaluasi sumatif yang dilakukan SD Muhammadiyah Sokonandi dilakukan pada akhir semester yang bertujuan untuk mengambil keputasan pada langkah selanjutnya. Apakah program tersebut dapat 
dilanjutkan atau memerlukan perbaikan. Selain itu evaluasi dilakukan setiap hari senin minggu ke-2 setiap bulannya. Evaluasi ini diikuti seluruh komponen dan berbentuk diskusi serta story telling sesuai pengalaman masing-masing pendidik. Evaluasi ini dilakukan dengan menyeluruh sebagai bahan untuk menyusun program selanjutnya.

4. Faktor Penghambat dan Pendukung dalam Pelaksanaan GLS

Pelaksanaan suatu program tentu akan terdapat faktor-faktor yang menjadi pendukung ataupun penghambat. Berikut adalah faktor pendukung dan penghambat dalam pelaksanaan program Geraka Literasi Sekolah di SD Muhammadiyah Sokonandi:

a. Faktor Pendukung

Berdasarkan hasil observasi dan wawancara yang dilaksanakan bahwa terdapat beberapa faktor pendukung yaitu:

1. Adanya sarana dan prasarana yang memadai, seperti perpustakaan, pojok baca, laoraturium komputer, proyektor disetiap kelas, lingkungan yang literat (dinding karya, papan prestasi, poster, kalimat positif di area sekolah, dan pemajangan penghargaan/piala prestasi peserta didik) yang dapat digunakan sebagai penunjang peningkatan program GLS.

2. Alokasi dana untuk kegiatan literasi yang memadai. Alokasi dana ini berasal dari RAPBS, DKT, dan dana iuran wali murid.

3. Terjalinnya kerja sama dengan beberapa organisasi seperti Dinas Pendidikan, Perpustakaan Keliling daerah, Ikhwam wali murid, dan komite sekolah untuk meningkatkan kegiatan literasi.

4. Adanya sodaqoh buku dari komite sekolah dan paguyuban wali murid.

5. Pemanfaatan media sebagai sumber literasi yang terus dikembangkan.

6. Adanya grup paguyuban wali murid sebagai jembatan penghubung antara sekolah dan keluarga.

b. Faktor Penghambat

Berdasarkan hasil observasi dan wawancara yang dilaksanakan bahwa terdapat beberapa faktor penghambat yaitu:
1. Perbedaan kemampuan dan inisiatif setiap SDM dalam mengembangkan kegiatan pendukung program GLS dan pengelolaan kelas untuk mengaktifkan literasi.

2. Kondisi peserta didik yang cepat bosan dengan bacaan dan perhatian yang mudah berpindah membuat pendidik harus menyusun ulang strategi pembelajaran yang telah direncanakan serta memberikan dorongan motivasi belajar.

3. Penyelenggaran kegiatan pendukung literasi yang terkadang tidak sesuai penjadwalan karena bersamaan dengan kegiatan wajib sekolah yang lain.

\section{PENUTUP}

Pelaksanaan program GLS di SD Muhammadiyah Sokonandi sesuai dengan panduan yang diterbitkan Kemendikbud, namun dalam pelaksanaannya SD Muhammadiyah Sokonandi mengembangkan secara mandiri dikarenakan sekolah ini menerapkan kurikulum irisan yaitu kurikulum nasional K13, kurikulum karakter building/muhammadiyah, dan kurikulum program plus. Dalam pelaksanaan GLS ini terbagi menjadi 3 bagian yaitu perencanaan, pelaksanaan, dan evaluasi. faktor pendukung yang ditemukan dalam proses pelaksanaan program GLS yaitu: sarana dan prasarana yang memadai yaitu: 2 unit perpustakaan, pojok baca, laboraturium komputer, lingkungan yang literat, alokasi dana yang memadai, terjalin kerja sama dengan beberapa lembaga, pemanfaatan media. Faktor penghambat yang ditemukan dalam proses pelaksanaan program GLS yaitu: perbedaan kemampuan dan inisiatif SDM, kurangnya strategi pemusatan perhatian literasi terhadap peserta didik, penyelenggaran kegiatan pendukung literasi yang tidak sesuai penjadwalan.

\section{UCAPAN TERIMA KASIH}

Kami mengucapkan terima kasih kepada Universitas Negeri Yogyakarta untuk kesempatan yang diberikan bagi kami untuk dapat membagikan hasil penelitian kami di Epistema. Kami juga menyampaikan terima kasih kepada Kepala Sekolah, guru-guru dan peserta didik SD Muhammadiyah Sokonandi untuk partisipasi dan dukungannya hingga penelitian ini dapat dipublikasikan. 
DAFTAR PUSTAKA

Abdulhak \& Darmawan. (2013). Teknologi Pendidikan. Bandung: Remaja Rosdakarya

Ahmadi. (2018). Tiga Tahap Pelaksanaan GLS. Diakses dari www.pediapendidikan.com pada tanggal 20 November 2019

Faizah, dkk. (2016). Panduan Gerakan Literasi Sekolah di Sekolah Dasar. Jakarta: Direktorat Pembinaan Sekolah Dasar Direktorat Jenderal Pendidikan Dasar dan Menengah Kementerian Pendidikan dan Kebudayaan
Moleong. (2009). Metodologi Penelitian Kualitatif. Bandung: PT Remaja Rosdakarya Offset

Sugiyono. (2014). Metode Penelitian Kuantitatif, Kulitatif, dan $R \& D$. Bandung: ALFABETA

Wiedarti, dkk. (2018). Desain Induk Gerakan Literasi Sekolah. Jakarta: Direktorat Jenderal Pendidikan Dasar dan Menengah Kementerian Pendidikan dan Kebudayaan 